\title{
The Effect of Life Review Therapy On The Level of Independence of Elderly At Panti Wredha St. Yoseph Kediri
}

\author{
Yoyok Febrijanto*, Erva Elli Kristanti, Dian Taviyanda \\ STIKES RS.Baptis Kediri, Indonesia \\ *yoyokfeb@gmail.com
}

\begin{abstract}
Old age is a normal stage of development that will be experienced by every individual who reaches old age and is a reality that cannot be avoided. Along with old age there are many setbacks, such as physical deterioration, which is characterized by the skin becoming wrinkled due to reduced, deteriorating vision, tooth loss, decreased appetite and other body conditions as well as slow activity. Life review is useful for increasing the individual's ability to carry out daily activities. The purpose of this study was to determine the effect of life review on the level of independence of the elderly at Panti Wredha St. Joseph Kediri. The design used in this study was a pre-experimental one group pre-post test design. The study population was the elderly at Wredha St. Yoseph Kediri who met the inclusion criteria. The sample of this study as many as 15 respondents were taken by purposive sampling. The independent variable is life review, while the dependent variable is the independence of the elderly in carrying out daily living activities at Panti Wredha St. Yoseph Kediri. The results showed that the level of independence before life review therapy with mild dependence was 11 respondents (68.8\%) and after being given life review therapy with mild dependence was 10 (62.5\%). Based on the Wilcoxon Sign Rank Test statistical test, it was obtained p 0.35 with a significance value of $\alpha<0.05$. Based on the results, it can be concluded that there is an influence of life review therapy with the independence of the elderly at Panti Wredha St. Yoseph Kediri.
\end{abstract}

Keywords: Life Review, Elderly, Level of Independence 


\section{STRADA Jurnal Ilmiah Kesehatan}

DOI: $10.30994 /$ sjik.v9i2.490

ISSN: 2252-3847 (print); 2614-350X (online)

Vol.9 No.2 November 2020 Page.1474-1480

\section{BACKGROUND}

The increasing number of elderly people in Indonesia continues to increase from year to year. The impact of this increase in the number of elderly people has an impact on the increasing number of diseases faced by the elderly. Some of the diseases that are often suffered by the elderly are emotional or mood changes that lead to depression (Iyus Yoseph, 2014). In addition, physical deterioration in physiology is also an obstacle to the ability of Daily Living, especially in self-care, such as: bathing, dressing, going to the toilet, transferring, continence, eating (Tamher, Noorkasiani, 2009) To increase the ability of Activity Daily Living in the elderly, it is necessary to have positive motivation and selfconfidence so that the elderly are able to do ADL independently. One of the activities that can increase self-confidence and independence is the Life Review Therapy.

The Indonesian Ministry of Health (2017) predicts population projection data, it is estimated that in 2017 there are 23.66 million elderly people in Indonesia (9.03\%). It is predicted that the number of elderly people in 2020 (27.08 million), 2025 (33.69 million), 2030 (40.95 million) and 2035 (48.19 million). Psychosocial factors in the elderly are a very burdensome problem in their lives, which in turn affect physical, social and mental disorders. The ability to do activities is a basic need that is absolutely expected by every human being. These abilities include standing, walking, working, eating, drinking, and so on. By doing activities the body will be healthy, the respiratory and circulatory systems of the body will function properly, and the body's metabolism can be optimal. Activity Daily Living is the main activity for self-care which includes: bathing, dressing, going to the toilet, transferring, continence, eating (Tamher, Noorkasiani, 2009). Therefore, an effort to increase self-confidence and independence is needed is the Life Review Therapy. Life review therapy was first put forward by Butler (1963) with the concept which states that life review therapy is a general mental psychological process that occurs naturally and is marked by the return of progressive awareness to past experiences. Life review therapy interventions are effective in increasing self-esteem, achieving self-integrity, reducing depression in the elderly, increasing satisfaction with life, providing a sense of peace (Wheeler, 2014). Based on the above review, the researcher is interested in conducting research on "Life Review Increases the Independence of the Daily Living Activity of the Elderly at Panti Wredha St. Yoseph Kediri.

\section{METHODS}

The research design used was a pre-experimental one group pre-post test design with the aim of seeing the effect of Life Review on the Level of ADL Independence in the elderly at Panti Wredha St. Yoseph Kediri. This research was conducted on 27 August 2020 - 27 September 2020 at Panti Wredha St. Yoseph Kediri by taking respondents according to the inclusion criteria through purposive sampling technique and the number of respondents who met the inclusion criteria was 16 respondents from a total of 30 respondents. The independent variable in the study is life review, while the dependent variable is the level of independence in the Activity Daily Living. Respondents in the study were given a questionnaire using the Bartel Index which was given twice before Life Review Therapy and after Life Review Therapy. 


\section{STRADA Jurnal Ilmiah Kesehatan}

DOI: $10.30994 /$ sjik.v9i2.490

ISSN: 2252-3847 (print); 2614-350X (online)

Vol.9 No.2 November 2020 Page.1474-1480

\section{RESULTS}

1. Characteristics of Respondents Based on Demographic Data of the Elderly at Panti Wredha St. Yoseph Kediri on 27 August 2020 - 27 September $2020(\mathrm{n}=16)$.

The characteristics of respondents at Panti Wredha St. Yoseph Kediri, it can be described that the minimum age of respondents is 60 years and the oldest is at 90 years of age. All of the respondents were female as many as 16 respondents (100\%) and more than $50 \%$ were married as many as 11 respondents $(68.8 \%)$ the average last elementary education was equivalent to $50 \%$ as many as 8 respondents $(50 \%)$, the frequency of visits was almost never as many as 9 respondents $(56 \%)$.

2. Characteristics of the level of independence before being given Life Review Therapy for the Elderly at Panti Wredha St. Yoseph Kediri.

Table 1. Level of Independence before being given Life Review Therapy for the Elderly at Panti Wredha St. Yoseph Kediri on 27 August 2020 - 27 September 2020 (n $=16$ ).

\begin{tabular}{|c|c|c|c|}
\hline \multicolumn{4}{|c|}{ Level of Independence } \\
\hline No & Category & Frequency & Percentage (\%) \\
\hline 1 & Independent & 0 & 0 \\
\hline 2 & Mild Dependent & 11 & 68.8 \\
\hline 3 & Moderate Dependent & 5 & 31.3 \\
\hline 4 & Severe Dependent & 0 & 0 \\
\hline & Total & 16 & 100 \\
\hline
\end{tabular}

Based on Table 1, it can be seen that the level of independence before being given Life Review Therapy for the elderly at Panti Wredha St. Yoseph Kediri is mostly mild dependence as many as 11 respondents $(68.8 \%)$ and the moderate level of dependence is 5 respondents $(31.3 \%)$.

3. Level of Independence after being given Life Review Therapy for the Elderly at Panti Wredha St. Yoseph Kediri on 27 August 2020 - 27 September $2020(\mathrm{n}=16)$.

Table 2 Level of Independence After being given Life Review Therapy for the Elderly at Panti Wredha St. Yoseph Kediri on 27 August 2020 - 27 September 2020 (n=16).

\begin{tabular}{|c|l|c|c|}
\hline \multicolumn{3}{|c|}{ Level of Independence } \\
\hline No & \multicolumn{1}{|c|}{ Category } & Frequency & Percentage (\%) \\
& & & 18.8 \\
1 & Independent & 10 & 62.5 \\
2 & Mild Dependent & 2 & 12.5 \\
3 & Moderate Dependent & 1 & 6.3 \\
4 & Severe Dependent & 16 & 100 \\
\hline & Total & & \\
\hline
\end{tabular}

Based on table 2, it shows that the level of independence after being given Life Review Therapy for the Elderly at Panti Wredha St. Yoseph Kediri is mostly mild dependence as many as 10 respondents (62.5), at the Independent level there are 3 respondents (18.8\%) while the Dependency Level Medium as many as 2 respondents (12.5\%) and Heavy Dependence as much as 1 respondent (6.3\%). 


\section{STRADA Jurnal Ilmiah Kesehatan}

DOI: $10.30994 /$ sjik.v9i2.490

ISSN: 2252-3847 (print); 2614-350X (online)

Vol.9 No.2 November 2020 Page.1474-1480

4. The Effect of Life Review Therapy on Increasing the Independence of the Elderly at Panti Wredha St. Yoseph Kediri on 27 August 2020 - 27 September $2020(\mathrm{n}=16)$.

Tabel 3. Level of Independence pre life review - Level of Independence post life review

\begin{tabular}{rr}
\hline & $-2.111^{\mathrm{b}}$ \\
\hline & .035
\end{tabular}

a. Wilcoxon Signed Ranks Test

b. Based on negative ranks.

Based on table 3 it can be seen that after a statistical test was carried out using the Wilcoxon signed rank test, it was found that $\rho=0.035$ with a significant value $\alpha<0.05$, if $\rho<\alpha$ means that $\mathrm{H} 0$ is rejected and $\mathrm{H} 1$ is accepted, so there is a significant effect after the life review therapy towards increasing the level of independence in the elderly at Panti Wredha St. Yoseph Kediri. This shows a significant effect.

\section{DISCUSSION}

1. The level of independence before being given life review therapy for the elderly at Panti Wredha St. Yoseph Kediri.

Based on the results of research on 16 respondents, it was found that the average age of the elderly in having a mild level of dependence was 11 respondents $(68.8 \%)$, and at a moderate level of dependence as many as 5 respondents (31.3\%), the minimum age of the respondents was 60 years and maximal. respondents are at the age of 90 years. The majority of the elderly with elementary education level or equivalent were 8 respondents $(50 \%)$ with almost never visit frequency of $9(56 \%)$.

According to Koesmanto in Azizah (2011), elderly people are grouped into young adults 18 or 25-29 years, full adult age (middle years) or maturity 29-60 years or 65 years, elderly (geriatric age) more. from 65 years or 70 years, which is further divided into 70-75 years (young old), 75-80 (old), more than 80 years (very old). Elderly is a natural process determined by God Almighty. Everyone will experience the process of getting old and old age is the last human lifetime. In this period, a person experiences gradual physical, mental and social decline (Azizah, 2011). This period is the initial period for the elderly to adapt to these changes. Changes that occur in the elderly, among others, are biological and psychological. Entering old age there are many setbacks, such as physical deterioration, which is marked by the skin becoming wrinkled due to reduced, deteriorating vision, tooth loss, activity slows down, appetite decreases and other body conditions also decline (Padila, 2013). Other changes occur in the musculoskeletal system where this system plays an important role in the body, changes that appear in the form of decreased muscle strength due to decreased muscle mass (muscle atrophy), muscle size becomes smaller and the decrease in muscle mass occurs more in the lower extremities. The dead muscle cells are replaced by connective tissue and fat. The strength or amount of force is produced by muscles decrease with age. Lower limb muscle strength decreases by $40 \%$ between the ages of 30 and 80 years

Based on the results of the study, the elderly at Panti Wredha St. Yoseph Kediri for the Dependence of the elderly were mild and moderate. In the elderly who experience a mild level of dependence, it is found that the elderly are still entering the 


\section{STRADA Jurnal Ilmiah Kesehatan}

DOI: $10.30994 /$ sjik.v9i2.490

ISSN: 2252-3847 (print); 2614-350X (online)

Vol.9 No.2 November 2020 Page.1474-1480

age of 60-65 years, where the decline in body function in these elderly people has not experienced a very significant reduction as evidenced by the fact that the elderly are still able to eat, take self-care baths, and mobilize independently. or only minimally assisted, this is proven by being able to eat with minimal assistance such as cutting or applying something to their food, taking a shower or walking they only need small help from other people. Changes in body function can also occur due to increasing age which can lead to changes in body functions. This is in accordance with the increasing age which results in changes in body functions. In accordance with the genetic clock theory, aging occurs as a result of biochemical changes programmed by molecules or DNA and each cell in time will undergo mutations. The cell mutation that occurs in the elderly's body causes a physiological decrease in the number of cells and this has an impact on decreasing body function. This decrease in body function can cause the elderly to experience a decrease in the level of independence, dependence on the level of independence that can be experienced in the elderly ranging from mild to severe.

Meanwhile, based on the results of the study, it was also found that the level of independence of the elderly is being influenced by the fact that the elderly who have a mild level of independence are still aged 65 years and over where the decline in body function in the elderly has started to decline as evidenced by the elderly in carrying out their activities such as; eating, bathing, self-care, mobilizing them. They carry out their own body functions. They are no longer strong so that if left untreated it can cause injury to the elderly. This is in line with the results of research that the elderly experience physical deterioration and in the end the elderly have mild to severe dependence.

2. The Effect of Life Review Therapy on Increasing the Independence of the Elderly at Panti Wredha St. Yoseph Kediri

Based on the results of the study, it was found that the life review had an effect on the improvement of the independence of the elderly at Panti Wredha St. Yoseph Kediri this is evidenced by the result of $\mathrm{p}=0.035$. The changes that occurred after doing life review therapy in the elderly found that 3 respondents had a level of independence independently (18.8\%) and a mild level of independence as many as 10 respondents $(62.5 \%)$

Life review is a therapy that involves memory of past events into a more positive story (Molinari, 1999 in Wheeler, 2014). According to Lestari and Nugraha (2017) through the process of reminiscing, elderly people can promote themselves, preserve personal and shared memories, overcome material shortages and physical limitations, identify universal themes about human life, and strengthen self-defense mechanisms. According to Setyoadi (2011) the benefits of life review therapy are as follows: Reducing depression, increasing self-confidence, increasing individual ability to perform daily activities and increasing life satisfaction. This therapy can be used as a pharmacological companion drug. In the implementation of life review therapy according to the stage of life development, it has several sessions that need to be explored in the elderly, including:

Session 1: Retelling the childhood and parents' childhood.

Session 2: Tells about adolescence: who are the most important people in life as a teenager.

Session 3: Describing adulthood: work that has been done and assessing the work that has been done. 


\section{STRADA Jurnal Ilmiah Kesehatan}

DOI: $10.30994 /$ sjik.v9i2.490

ISSN: 2252-3847 (print); 2614-350X (online)

Vol.9 No.2 November 2020 Page.1474-1480

Session 4: Telling the old age: telling happy events that have been experienced. Based on the application of this life review therapy, we can find out whether the elderly still have the spirit of motivation in living their old age.

Based on the results of the study, it was found that life review therapy had an effect on the Increasing Independence of the Elderly at Panti Wredha St. Yoseph Kediri, this is proven that there is a significant change in the level of independence experienced by the elderly from before the life review therapy and then the life review therapy, which is initially the level of independence of the mild and moderate elderly after life review therapy, the elderly experienced a change in having a level of independence independently get to light. Diman Elderly, who initially had a mild level of independence, were motivated by telling their life experiences in each life review therapy session so that they are now able to carry out their activities independently without the help of others. This is evidenced from the start of the elderly eating (Feeding), bathing (bathing), self-care (grooming), dressing (dressing), urinating (bowel), defecating (bladder), use of the toilet, transfer, mobility, climbing. down the stairs they can do it independently or only with the help of tools at least once. This is in line with the theory that Life review is a therapy that involves memory of past events into a more positive story (Molinari, 1999 in Wheeler, (2014) Life review therapy is a broad phenomenon as a description of the experience of events, where wherein someone will see quickly about the totality of his life history (Setyoadi, 2011).

\section{CONCLUSION}

The results of the study can be concluded that the Life Review Therapy is very influential on the Improvement of the Independence of the Elderly at Panti Wredha St. Yoseph Kediri is proven by the value of $\mathrm{P}=0.035$. Where before the Life Review therapy was given, there were 11 respondents $(68.8 \%)$ and 5 respondents $(68.8 \%)$ who were given the Independence Level, while after the life review therapy, there were 3 respondents $(18.8 \%)$ of the elderly independently. and Independence Level of Mild Elderly as many as 10 respondents (62.5\%). The management at Panti Wredha St. Yoseph Kediri is very pleased with the introduction of this Life review therapy so that the nursing staff can also apply it on an ongoing basis to the elderly.

\section{REFERENCES}

Barbara K. Haight (2016). The Therapeutic Role of a Structured Life Review Process in Homebound Elderly Subjects. College of Nursing, Medical University of South Carolina.

Dea, (2015). PengaruhTerapi Modalitas Life Review Terhadap Tingkat Stress Pada Lansia

Di Panti Werdha Ilomata Kota Gorontalo. Jurnal Ungaran Gorontalo.

E. T. Bohlmeijer, G. J. Westerhof (2013). Life Review as a Way to Enhance Personal Growth in Midlife: A Case Study.Journal University of Twente.

Elizabeth, Corwin. (2000). Patofisiologis. Penerbit Buku Kedokteran. EGC. Jakarta.

FIK UI. (2005). Kumpulan Materi Keperawatan Neurologi. Jakarta.

Gofir, Abdul. (2009). Evidence Base Medicine ; Manajemen Stroke. Pustaka Cendekia Press. Yogyakarta

Iyus J, Titin S, (2014). Buku Ajar Keperawatan Jiwa. Bandung: Refika Aditama, hal: 281.

Kathleen Wheeler (2014). Psychotherapy For The Advanced Practice Psychiatric Nurse,

Second Edition : A How To Guide For Evidence Based Practice. New York: Springer Publishing Company. 


\section{STRADA Jurnal Ilmiah Kesehatan}

DOI: $10.30994 /$ sjik.v9i2.490

ISSN: 2252-3847 (print); 2614-350X (online)

Vol.9 No.2 November 2020 Page.1474-1480

Manoj Sharma, AshutoshAtri, Paul Branseum (2013). Foundations of Health Promotion.Burlington: Jones \&Barlett Learning, L.L.C, an Aseend Learning Company.

Marjorie, Linda Norlander (2009), Being Present A Nurse's End of Life Communication. Canada: Sigma Theta Tau International.

Muhammad, Sasmiyanto, Susi (2014). Pengaruh Life Review Therapy Terhadap Kualitas Hidup Lansia Di Dinas Unit Pelaksana Teknis Pelayanan Sosial Lanjut Usia Kabupaten Bondowoso. Universitas Muhammadiyah Jember.

Nursalam, (2013). Metodologi Penelitian Ilmu Keperawatan Pendekatan Praktis Edisi 3. Jakarta: Salemba Medika.

Nursalam, (2015). Metodologi Penelitian Ilmu Keperawatan Pendekatan Praktis Edisi 4. Jakarta: Salemba Medika.

Nursalam, (2016). Konsep dan Penerapan Metodologi Penelitian Ilmu Keperawatan. Jakarta: Salemba

Padila, (2013). Buku Keperawatan Gerontik. Yogyakarta: Nuha Medika

Robyn M, Josephine, Phyllis (2015). Therapeutic Life Review in Palliative Care: A systematic Review of Evaluations. Journals Universityof Sydney.

Setyoadi, Kusharyiadi (2011). Terapi Modalitas Keperawatan pada Klien Psikogeriatik. Jakarta: Salemba Medika.

Sue Wheeler (2006), Difference AndDiversity in Councelling Contemporary Psychodynamic Perspectives. New York: Palgrav Macmillan.

Titik L, (2015). Kumpulan Teori untuk Kajian Pustaka Penelitian Kesehatan. Yogyakarta: Nuha Medika. 